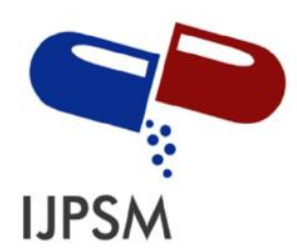

Eldya Nurismi et al, Int. Journal of Pharmaceutical Sciences and Medicine (IJPSM),

Vol.6 Issue. 5, May- 2021, pg. 32-39

ISSN: 2519-9889

Impact Factor: 3.426

\title{
Review: Effect of Different Methods on the Multicomponents Crystal Formation from Medicinal Natural Ingredient Compounds
}

\author{
Eldya Nurismi; Henni Rosaini; dan Maria Dona Octavia \\ School of Pharmaceutical Science (STIFARM) Padang 25174, Indonesia \\ e-mail: eldyanurismi12@gmail.com \\ DOI: 10.47760/ijpsm.2021.v06i05.004
}

\begin{abstract}
Solubility is an important parameter for the bioavailability of drugs that are difficult to dissolve. Natural compounds that are included in class II in the Biopharmaceutics Classification System (BCS) are Apigenin, Quercetin, Genistein, Curcumin, and Piperin. These drugs have low solubility in water and high permeability so that they affect the dissolution rate and as well as their bioavailability, to increase the solubility they are made with multicomponent crystals. This review aims to provide information on the method of making crystal multicomponent to increase the solubility and dissolution rate of BCS II drugs. Several methods that can be used in multicomponent are solvent drop grinding, solvent evaporation, assisted grinding, and slurry. The results showed that multicomponent crystals using several methods could increase the solubility and dissolution rates.
\end{abstract}

Keyword: Crystal Multicomponent, Biopharmaceutics Classification System II, Solubility, Dissolution rate

\section{Introduction}

Solubility is an important parameter for desired concentration of drug enters the systemic circulation directly [1]. The term solubility means an amount of solute that can be dissolved in a certain. It is can be defined qualitatively or quantitatively. Qualitatively, solubility is the interaction between two or more substances that will form a phase. Quantitatively, solubility is the concentration of the solute in a saturated solution at a certain temperature [2].

Low drug solubility in water resulting in low drug absorption in the gastrointestinal fluids. To optimize absorption, it is important to increase the rate of dissolution [3]. The Biopharmaceuticals Classification System (BCS) divides drugs into four classes, namely: class I high solubility and high permeability, class II low solubility and high permeability, class III high solubility and low permeability, and class IV low solubility and low permeability [4]. To improve the low solubility of drugs such as class II and IV, it can be formulated as a crystal multicomponent.

Multicomponent is an effective method because it can be used to improve physicochemical properties such as solubility, dissolutions rate, and stability. Multicomponent crystals are formed when more than one molecule 


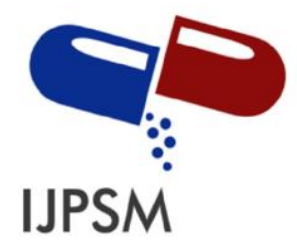

Eldya Nurismi et al, Int. Journal of Pharmaceutical Sciences and Medicine (IJPSM),
Vol.6 Issue. 5, May- 2021, pg. 32-39

ISSN: 2519-9889

Impact Factor: 3.426

has been crystallized together in a crystal lattice through non-covalent interactions. The advantages of multicomponent crystals are stable crystalline than amorphous, excessive solubility and bioavailability, using purification techniques, and not breaking covalent bonds [5]. Several methods were used in multicomponent crystals, such as solvent drop grinding, solvent evaporation, assisted grinding, and slurry. This article review aims to provide information on the method of manufacture multicomponent crystals from natural materials to increase solubility, the rate of dissolution of drugs classified into BCS II.

\section{Data Collection}

This review article was created by using the technique literature study method in the form of national and international journals published in the last 20 years (2000-2020). In creating a review of this article, we used data search on online media with the keywords were multicomponent crystals, solubility, dissolution rate, and BCS II drugs. The main reference search in this review was carried out through trusted websites such as Google Scholar, ScienceDirect, Researchgate, and other published and trusted journal databases.

\section{Multicomponent Crystals}

One way to improve drug solubility without changing its pharmacological activity can be done by modifying the solid form by made multicomponent crystals, namely salts and co-crystals [6]. The multicomponent crystals consist of co-crystals, salt, and solvate that interact between the two solid phases and form either a cocrystalline phase of salt [7].

Multicomponent crystals are the crystals with two or more different (2D structure and elements) or other different but not opposite chirality, and residues in the crystal lattice [8]. The classification of crystal multicomponent is divided into cocrystal, hydrate, and salt. Cocrystal is a solid crystal containing more than one solid component which aims to modify the physicochemical properties of the Active Pharmaceutical Ingredient (API). Cocrystal is a solid of two or more molecules that form the crystal lattice different molecular bonds are linked by hydrogen bonds and Van der Waals. The cocrystallization technique is a simple and attractive method to increase to improve drug solubility and bioavailability in the water [9]. The cocrystallization method has several advantages including it does not affect the pharmacological activity of the active substance, however, it improves physical properties such as dissolution rate, solubility, and compressibility [10].

Salt is the compound formed by the transfer of protons from one compound to another. Salts and co-crystals can be differentiated based on a proton transfer from an acid to a base [5]. The formation of the salt occurs when the proton transfers from a pharmaceutical active ingredient to the salt-forming agent, while the formation of cocrystal occurs due to the hydrogen bonding between the active pharmaceutical ingredient and the co-crystal forming material [11]. Salt is used in the place of free acid and base in order of improved solubility, crystalline property, and stability. Salt is formed by the transfer of a proton from the acid to bases. Crystals and salts are conformers and drugs which are intermolecular solids that are nonionic [12].

Hydrates belong to the solvate class because the molecules belong to a crystal lattice. Hydrates are crystals with solvent molecules added with a coformer or consisting of two ions. Solvates or hydrates are formed during the co-crystallization via solution or liquid-assisted grinding and they can alter physicochemical properties. Solvate has insoluble stability due to the presence of solvents in the crystal lattice [5]. 


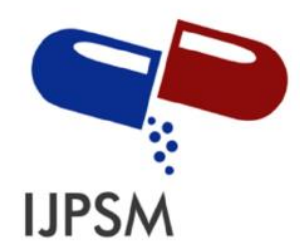

Eldya Nurismi et al, Int. Journal of Pharmaceutical Sciences and Medicine (IJPSM), Vol.6 Issue. 5, May- 2021, pg. 32-39

ISSN: 2519-9889

Impact Factor: 3.426

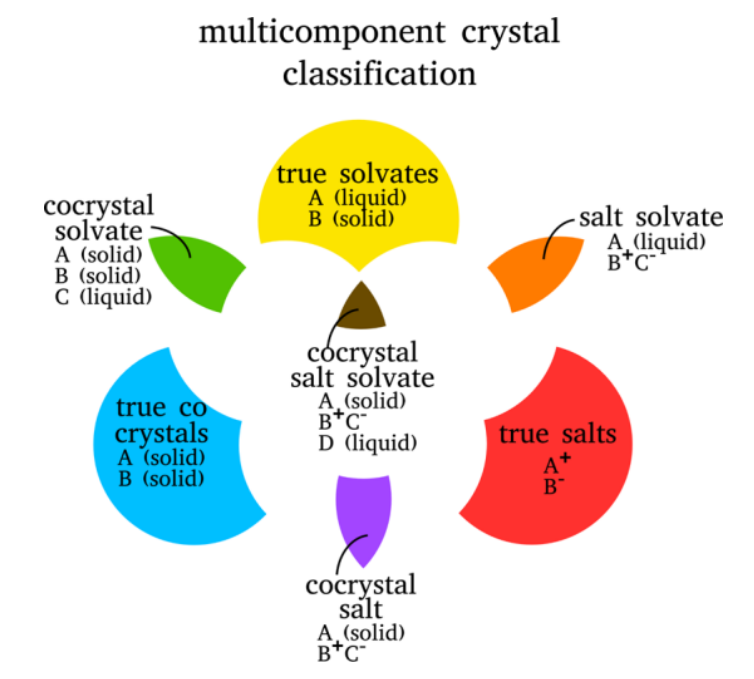

Figure 1. Classification of Multicomponents Crystal [8]

\section{Method of Manufacture}

\section{Solvent Drop Grinding}

Solvent drop grinding is an alternative method to produce new molecular materials. The technique is considered easy and environmentally friendly with minimum use of solvents [13]. Solvent drop grinding is a solid grinding technique by adding two ingredients with minimum use of solvent. Solvents are usually used in minimum quantities when added as a catalyst. Solvent drop grinding has a simple method but takes a long time in the grinding process [14]. In albendazole drugs that have low solubility, the solubility and dissolution rates increase by 115 times using the multicomponent solvent drop grinding method [11].

\section{Solvent Evaporation}

Solvent evaporation is a simple technique in the manufacture of cocrystal using a coformer with a suitable solvent. Molecular interactions on the solubility process of the two compounds form hydrogen bonds in the cocrystallization process. The solvent evaporation process aims to remove the solvent, resulting in the formation of crystalline solids which have different physicochemical properties from the pure substance [15]. This method has the advantage of being thermodynamically produced cocrystal [16]. Several studies reported that the BCS class II multicomponent crystal formulation using this method can improve bioavailability such as simvastatin and ketoprofen [17][18].

\section{Assisted Grinding}

Assisted grinding is a liquid-assisted grinding which forms a faster cocrystalline phase compared to c-assisted grinding. This assisted grinding method uses a saturated solvent to form a cocrystal phase [19]. This method uses a minimum of solvent, not depending on the temperature, and also environmentally friendly [20]. The Assisted grinding method is an alternative method, environmentally friendly, and can be used for the 


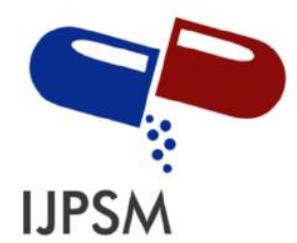

Eldya Nurismi et al, Int. Journal of Pharmaceutical Sciences and Medicine (IJPSM), Vol.6 Issue. 5, May- 2021, pg. 32-39

ISSN: 2519-9889

Impact Factor: 3.426

preparation of materials that cannot be done by solid-state grinding. In the BCS class II drugs (zaltoprofen and furosemide) there was an increase in solubility of 166,666.67 times using assisted grinding [21].

\section{Slurry}

The slurry method is a method that can be used as an alternative to making cocrystal. In this method, a muddy or suspension is formed by adding a small amount of solvent. API and conformer suspension added in a solvent and then stirring until the formation process is completed cocrystal. cocrystal method, namely the establishment of cocrystal using a slurry method with the aid of sonication, it is known that the concentration of the solvent added has a major role in the rate of formation of cocrystal. Cocrystal can be formed from the active substance and its coformer in the saturation phase with the solvent used [22]. The advantages of the slurry method include using a simple solvent, efficient in cocrystal manufacture, and the preparation of the cocrystal it is carried out at room temperature for six days [23]. Based on Dwi Setyawan's research on the drug loratadine (BCS class II drug) there was an increase in solubility and dissolution rate using the slurry method [24]. Some of the successes of the multicomponent method on the BCS class II active substances resulted in an increase in the dissolution rate at table 1.

Table 1: Multicomponent manufacturing method for active substance BCS class II

\begin{tabular}{|c|c|c|c|c|c|c|c|}
\hline No & $\begin{array}{c}\text { Active } \\
\text { substance }\end{array}$ & Coformer & Methods & Solvent & Differents & Characterization & $\overline{R e f}$ \\
\hline 1. & Apigenin & Bipyridine & $\begin{array}{l}\text { Solvent drop } \\
\text { grinding, } \\
\text { Slurry }\end{array}$ & $\begin{array}{l}\text { Ethanol } \\
\text { Ethanol and } \\
\text { dichloromet } \\
\text { hane }\end{array}$ & $\begin{array}{c}271 \mathrm{mg}: 156 \\
\mathrm{mg} \\
271 \mathrm{mg}: 312 \\
\mathrm{mg}\end{array}$ & $\begin{array}{l}\text { PXRD, FT-IR, } \\
\text { DSC, } \\
\text { Dissolutions . }\end{array}$ & [25] \\
\hline \multirow[t]{5}{*}{2.} & Quercetin & Succinic acid & $\begin{array}{l}\text { Solvent } \\
\text { evaporation }\end{array}$ & Molar & $1: 1$ & $\begin{array}{l}\text { DSC, PXRD, FT- } \\
\text { IR, SEM, } \\
\text { Dissolution }\end{array}$ & [26] \\
\hline & & Succinic acid & $\begin{array}{l}\text { Assisted } \\
\text { grinding }\end{array}$ & Methanol & $1: 1$ & $\begin{array}{l}\text { DTA, PXRD, } \\
\text { SEM, } \\
\text { Dissolution }\end{array}$ & [27] \\
\hline & & $\begin{array}{l}\text { isonicotinamid } \\
\mathrm{e}\end{array}$ & $\begin{array}{l}\text { Solvent } \\
\text { evaporation }\end{array}$ & Ethanol & $1: 1$ & $\begin{array}{l}\text { DSC, PXRD, } \\
\text { SEM, } \\
\text { Dissolution }\end{array}$ & {$[28]$} \\
\hline & & Malonic acid & $\begin{array}{ll}\begin{array}{l}\text { Solvent } \\
\text { grinding }\end{array} & \text { drop } \\
\end{array}$ & Ethanol & $1: 1$ dan $1: 2$ & $\begin{array}{l}\text { DSC, PXRD, FT- } \\
\text { IR, SEM, } \\
\text { Dissolution }\end{array}$ & [29] \\
\hline & & caffeine & Slurry & Methanol & $58,23 \mathrm{mg}$ & $\begin{array}{ll}\text { DSC, } & \text { FT-IR, } \\
\text { PXRD } & \end{array}$ & [30] \\
\hline 3. & Genistein & Caffeine & $\begin{array}{l}\text { Solvent drop } \\
\text { grinding, } \\
\text { Slow } \\
\text { evaporation, } \\
\text { Slurry }\end{array}$ & $\begin{array}{l}\text { Methanol } \\
\text { Ethyl } \\
\text { alcohol } \\
\text { Methanol }\end{array}$ & $\begin{array}{c}1: 1 \\
\\
25,0 \mathrm{mg}: \\
17,9 \mathrm{mg} \\
2000,0 \mathrm{mg}: \\
1435,8 \mathrm{mg}\end{array}$ & $\begin{array}{l}\text { FT-IR, PXRD, } \\
\text { DTA, } \\
\text { Dissolution }\end{array}$ & [31] \\
\hline
\end{tabular}




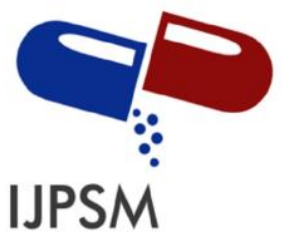

Eldya Nurismi et al, Int. Journal of Pharmaceutical Sciences and Medicine (IJPSM), Vol.6 Issue. 5, May- 2021, pg. 32-39

ISSN: 2519-9889

Impact Factor: 3.426

\begin{tabular}{|l|l|l|l|l|c|l|l|}
\hline & & $\begin{array}{l}\text { Pyridinecarbo } \\
\text { xamide }\end{array}$ & $\begin{array}{l}\text { Solvent drop } \\
\text { grinding, }\end{array}$ & $\begin{array}{l}\text { Methanol, } \\
\text { Ethanol, } \\
\text { Etyl acetat }\end{array}$ & $1: 1$ & $\begin{array}{l}\text { FT-IR, DSC, } \\
\text { SEM }\end{array}$ & {$[32]$} \\
\hline 4. & Piperine & Nicotinic acid & $\begin{array}{l}\text { Solvent } \\
\text { evaporation }\end{array}$ & Ethanol & $1: 1$ & $\begin{array}{l}\text { SEM, DSC, } \\
\text { Difraksi Sinar-X, } \\
\text { FT-IR, } \\
\text { Dissolution }\end{array}$ & {$[33]$} \\
\hline 5. & Curcumin & Ascorbic acid & $\begin{array}{l}\text { Solvent } \\
\text { evaporation }\end{array}$ & Methanol & $3 \mathrm{mg}$ & $\begin{array}{l}\text { DSC, PXRD, FT- } \\
\text { IR }\end{array}$ & {$[35]$} \\
\hline & & $\begin{array}{l}\text { Resorcinol } \\
\text { pyrogallol }\end{array}$ & $\begin{array}{l}\text { Liquid assisted } \\
\text { grinding }\end{array}$ & Ethanol & $1: 1$ dan 1:1 & $\begin{array}{l}\text { DSC, PXRD, FT- } \\
\text { IR }\end{array}$ & {$[36]$} \\
\hline
\end{tabular}

Ma et al., (2019) reported that the formulation of the active substance apigenin-bipyridine coformer increased dissolution rate by 40 times with a ratio of $271 \mathrm{mg}: 156 \mathrm{mg}$. The PXRD test showed the formation of the cocrystal phase, DSC and X-rays confirm the formation of the cocrystal. FT-IR showed that there are hydrogen bonds and molecular [25].

Setyawan (2017) reported that the formulation of the active substance Quercetin using a Succinic acid coformer can increase the dissolution rate of cocrystal higher than pure quercetin with a ratio of 1 : 1 . In the PXRD test, new peaks are formed suggest the formation of the cocrystal phase. FT-IR results demonstrated the interaction between components in the functional group -OH at the wavelength of $1830 \mathrm{~cm}-1$. In the SEM test the formation of new crystalline particles with smaller particle sizes [26].

Athiyah et al., (2018) reported that quercetin interacts with succinic acid improves dissolution rate by 1.25 higher than pure quercetin with a ratio of 1: 1. In the DTA test, a new crystalline phase has been formed which melts around $280^{\circ} \mathrm{C}$. The PXRD results showed a change in the crystal lattice. FTIR is used to observe the interactions between the two or more different components that form the cocrystal phase held by hydrogen bonding. The SEM test shows that the interaction between quercetin and succinic acid only occurs at the interface [27].

Several studies reported that the formulation of the active substance Quercetin using the isonicotinamide coformer can improve dissolution rate by $83.3 \%$ with a ratio of $1: 1$. The DSC test showed a new endothermic peak was formed at a melting point of $255.26^{\circ} \mathrm{C}$. The PXRD test showed the formation of a new solid phase different from the diffractograms. SEM test showed that the formation of crystals with a new crystal morphology. Based on the results of FTIR analysis, it shows that the interaction between the two components at a wavelength of 3413.52 and $3215.52 \mathrm{~cm}-1$ [28].

Setyawan et al. (2018) formulated the active substance Quercetin with coformer malonic acid, ethanol solvent using the solvent drop grinding method. The results showed that it could increase the dissolution rate by 1,056 times with a ratio of $1: 1$ and 1: 2 . In the DSC test, the formation of endothermic peaks at 283.02 and 266.61 indicates the formation of cocrystal. PXRD test results showed the formation of new diffraction with the formation of a new crystal phase. PXRD test results showed the formation of new diffraction with the formation of a new crystal phase. SEM test results showed a change in the shape of the needle-shaped crystal and pebble-shaped crystals, with the formation of a new crystal phase [29].

Smith et al., (2011) formulated the active substance Quercetin using the Caffeine coformer and methanol as a solvent. The results show that it can increase the dissolution rate by 14 times the ratio of $58.23 \mathrm{mg}$. The crystal structure of Quercetin with the caffeine coformer which forms crystals confirmed from PXRD, FT-IR, and 


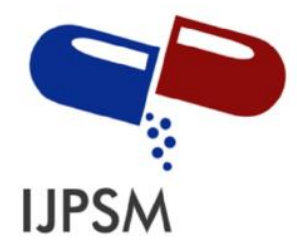

Eldya Nurismi et al, Int. Journal of Pharmaceutical Sciences and Medicine (IJPSM), Vol.6 Issue. 5, May- 2021, pg. 32-39

ISSN: 2519-9889

Impact Factor: 3.426

DSC tests. The PXRD test revealed that QUECAF is isostructural to QUECAF $3 \mathrm{MeOH}$. The DSC test confirms the presence of crystals that are still stable and have the same the dissolved melting point. [30]. Some studies reported that the dissolution rate of genistein with the caffeine coformer reaches $0.861 \mathrm{mg} / \mathrm{ml}$ after 8 hours. In the x-ray diffraction analysis the formation of cocrystal compounds [31].

Sowa et al (2013) formulated the active substance genistein with a pyridinecarboxamide coformer using the solvent drop grinding method and methanol, ethanol, and ethyl acetate as solvents. The results show that the formula can increase the dissolution rate by a ratio of $1: 1$. The solvent drop grinding method that application of pyridinecarboxamide coformers is a successful approach towards the preparation of flavonoid cocrystals by both solvent drop grinding method and cocrystallization from solution [32].

Yeni (2019) reported that the formulation of the active substance Piperine with the nicotinic acid coformer increased the dissolution rate by $52.95 \%$. New crystalline particles have irregular rod-shaped and nicotinic acid crystals, with reduced particle size by SEM. It was confirmed by the X-ray diffraction analysis that new crystals were formed which differed from pure piperine. The results of the multicomponent FT-IR spectrum of piperine-nicotinic acid crystals have a wavenumber of $3349.94 \mathrm{~cm}-1$, namely O-H [33].

Erizal et al., (2020) reported that the formulation of the active substance Piperin-Succinic Acid increased the dissolution rate by $99 \%$. The DSC test showed a single and sharp endothermic peak at $110.49 \mathrm{C}$. In the PXRD test, the intact piperine pattern showed different and sharp diffraction peaks at $2 \Theta$ values of the solid form with highly crystalline properties. The FTIR spectrum showed the peaks at $2936 \mathrm{~cm}-1$ and $2600 \mathrm{~cm}$ indicated O-H stretching from the hydrogen bond between the hydrogen of succinic acid and the ketone oxygen of piperine. Single crystal structure analysis shows two piperine and one succinic acid are form groups of three molecules that linked by hydrogen bonds [34].

Pantwalawalkar et al., (2020) showed that the formulation of the active substance curcumin- ascorbic acid coformer increased the dissolution rate by 576 times in distilled water and 10 times in buffer. The DSC test showed that the first endothermic peak corresponds to eutectic melting and the second endothermic peak corresponds to melting crystals. This PXRD test has the appearance of a sharp peak which can confirm the nature of curcumin crystals. The FTIR spectrum of solvent evaporated curcumin-ascorbic acid mixture also confirmed hydrogen interactions enabling cocrystal formation [35].

Sanphui et al., (2011) showed that the formulation of the active ingredient curcumin-resorcinol and curcuminpyrogallol in $40 \%$ EtOH-water can increase dissolution rates $\sim 12$ and $\sim 5$ times faster. In the DSC test, the presence of a single endothermic peak at different temperatures and melting points indicates a single crystal phase. In the XRD test, the formation of a new phase occurs due to the formation of a new polymorph during the milling process. The changes in the $\mathrm{O}-\mathrm{H}$ and $\mathrm{C}=\mathrm{O}$ stretching frequencies of the cocrystals compared to the coformers suggested the formation of new compounds [36].

\section{Conclusion}

Multicomponent is an effort to increase the solubility of drugs with low levels of solubility in water, such as apigenin, quercetin, genistein, piperine and curcumin. Several methods that can be used in multicomponent include solvent drop grinding, solvent evaporation, assisted grinding and slurry. The best method is slurry. This method can increase the dissolution rate by $99 \%$ in piperine compounds. 


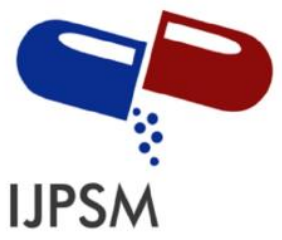

Eldya Nurismi et al, Int. Journal of Pharmaceutical Sciences and Medicine (IJPSM), Vol.6 Issue. 5, May- 2021, pg. 32-39

\section{References}

[1] Patel, J. N., Rathod, D. M., Patel, N. A., Modasiya, M. K. (2012). Techniques to Improve the Solubility of Poorly Soluble Drugs. International Journal of Pharmacy \& Life Sciences, 3 (2), 1459-1469.

[2] Vemula, V. R., Lagishetty, V., Lingala, S. (2010). Solubility Enhancement Techniques. International Journal of Pharmaceutical Sciences Review and Research, 5 (1), 41-51.

[3] Gao, P., Shi, Y. (2012). Characterization of Supersaturatable Formulations for Improved Absorption of Poorly Soluble Drugs. American Association of Pharmaceutical Scientists, 14 (4), 703-713.

[4] Savjani, K. T., Gajjar, A. K., Savjani, J. K. (2012). Drug Solubility: Importance and Enhancement Techniques. International Scholarly Research Network Pharmaceutics, 2012 (3), 1-10.

[5] Samineni, R., Chimakurthy, J., Sumalatha, K., Dharani, G., Rachana, J., Manasa, K., Anitha, P. (2019). CoCrystals: A Review of Recent Trends in Co Crystallization of BCS Class II Drugs. Research Journal of Pharmacy and Technology, 12 (7), 3117-3124.

[6] Domingos, S., André, V., Quaresma, S., Martins, I. C. B., Minas, Da. Piedade. M. F., Duarte, M. T. (2015). New Forms of Old Drugs: Improving Without Changing. Journal Pharmacy Pharmacology, 67 (6), 830-846.

[7] Yuliandra. Y., Izadihari, R., Rosaini, H., Zaini, E. (2019). Multicomponent Crystals of Mefenamic AcidTromethamine with Improved Dissolution Rate. Journal Research in Pharmacy, 23 (6), 988-996.

[8] Grothe, E., Meekes, H., Vlieg, E., Ter, Horst. J. H., De, Gelder. R. (2016). Solvates, Salts, and Cocrystals: A Proposal for a Feasible Classification System. American Chemical Society, 16 (6), 3237-3243.

[9] Zaini, E., Halim, A., Soewandhi, S. N., Setyawan, D. (2011). Peningkatan Laju Pelarutan Trimetoprim Melalui Metode Ko-kristalisasi Dengan Nikotinamida. Jurnal Farmasi Indonesia, 5 (4), 205-212.

[10] Gozali, D., Bahti, H. H, Soewandhi, S. N., Abdassah, M. (2014). Pembentukan Kokristal Antara Kalsium Atorvastatin Dengan Isonikotinamid Dan Karakterisasinya. Jurnal Sains Materi Indonesia, 15 (2), $103-110$.

[11] Alatas, F., Azizsidiq, F. A., Sutarna, T. H., Ratih, H., Soewandhi, S. N. (2020). Perbaikan Kelarutan Albendazol Melalui Pembentukan Kristal Multikomponen dengan Asam Malat. Jurnal Farmasi Galenika, 6 (1), $114-123$.

[12] Vitthalrao, M. A., Kumar, F. N., Radheshyam, B. K. (2013). Review Article Cocrystalization: an Alternative Approach for Solid Modification. Journal of Drug Delivery and Therapeutics, 3 (4), 166-172.

[13] Paredes, J. H., Pesqueira, F. J. C., Ponce, H. E. E., Negrete, O. H., Ramos, M. E. A. (2015). L-Proline-Sodium Nitrate Obtained from Solvent Drop Grinding. Polyhedron, 91, 84-88.

[14] Triayana, R., Nurhabibah., Sopyan, I. (2021). Artikel Review: Kokristal, Kokristal Ibuprofen dengan Berbagai Koformer, Virtual Screening Tools. Majalah Farmasetika, 6 (1), 23-37.

[15] Hairunnisa., Sopyan, I., Gozali, D. (2019). Cocrystal: Nicotinamide as the Coformer. Jurnal Ilmiah Farmako Bahari, 10 (2), 113-122.

[16] Jayasankar, A., Somwangthanaroj, A., Shao, Z. J., Hornedo, N. R. (2006). Cocrystal Formation During Cogrinding and Storage is Mediated by Amorphous Phase. Pharmaceutical Research, 23 (10), 2381-2392.

[17] Sopyan, I., Fudholi, A., Muchtaridi, M., Sari, I.P. (2017). Simvastatin-Nicotinamide Co-crystal: Design, Preparation and Preliminary Characterization. Tropical Journal Pharmaceutical Research, 16 (2), $297-303$.

[18] Wicaksono, Y., Setyawan, D., Siswandono, S. (2018). Multicomponent Crystallization of KetoprofenNicotinamide for Improving the Solubility and Dissolution Rate. Chemistry Journal of Moldova, 13 (2), $74-81$.

[19] Alhalaweh, A., George, S., Basavoju, S., Childs, S. L., Rizvi, S. A. A., Velaga, S. P. (2012). Pharmaceutical Cocrystal of Nitrofurantion: Screening, Characterization and Crystal Structure Analysis. Royal Society of Chemistry, 14, 5078-5088.

[20] Trask, A. V., Jones, W. (2005). Crystal Engineering of Organic Cocrystals by the Solid-State Grinding Approach. Top Curr Chem, 254, 41-70.

[21] Rachmaniar, R., Tristiyanti, D., Sari, S. D. (2020). [Review] Pengaruh Koformer Nicotinamide dan Metode Pembentukan Kokristal Terhadap Kelarutan Zat Aktif Tidak Larut Air. Jurnal Sains dan Teknologi Farmasi Indonesi, IX (1), 27-40.

[22] Rahman, F., Winantari, A. N., Siswandono., Setyawan, D. (2017). Comparison Study of Grinding and Slurry Method on Physicochemical Characteristic of Acyclovir - Succinic Acid Cocrystal. Asian Journal of Pharmaceutical and Clinical Research, 10 (3), 153-158.

[23] Setyawan, D., Wardhana, N. K., Sari, R. (2015). Solubility, Dissolution Test and Antimalarial Activity of Artesunate Nicotinamide Co-crystal Prepared by Solvent Evaporation and Slurry Methods. Asian Journal of Pharmaceutical and Clinical Research, 8 (2), 164-166.

[24] Setyawan, D., Paramanandana, A., Erfadrin, V. E., Sari, R., Paramita, D. P. (2020). Compression Force Effect on 


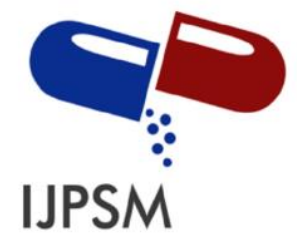

\section{Eldya Nurismi et al, Int. Journal of Pharmaceutical Sciences and Medicine (IJPSM), Vol.6 Issue. 5, May- 2021, pg. 32-39}

Characteristics of Loratadine-Succinic Acid Cocrystal Prepared by Slurry Method. Journal of Research in Pharmacy, 24 (3), 410-415.

[25] Ma, X. Q., Zhuang, C., Wang, B. C., Huang, Y. F., Chen, Q., Lin, N. (2019). Cocrystal of Apigenin with Higher Solubility, Enhanced Oral Bioavailability, and Anti-inflammatory Effect. American Chemical Society, 19 (10), 5531-5537.

[26] Setyawan, D., Oktavia, I. P., Farizka, R., Sari, R. (2017). Physicochemical Characterization and In Vitro Dissolution Test of Quercetin-Succinic Acid Co-crystals Prepared Using Solvent Evaporation. Turkish Journal of Pharmaceutical Sciences, 14 (3), 280-284.

[27] Athiyah, U., Kusuma, P. A., Tutik., Lestari, M. L. A. D., Isadiartuti, D., Paramita, D. P., Setyawan, D. (2019). Crystal Engineering of Quercetin by Liquid Assisted Grinding Method. Jurnal Teknologi, 81 (1), 39-45.

[28] Wisudyaningsih, B., Setyawan, D., Siswandono. (2019). Co-crystallization of Quercetin and Isonicotinamide Using Solvent Evaporation Method. Tropical Journal of Pharmaceutical Research, 18 (4), 697-702.

[29] Setyawan, D., Jovita, R. O., Iqbal, M., Paramanandana, A., Yusuf, H., Lestari, M. L. A. D. (2018). Cocrystalization of Quercetin and Malonic Acid Using Solvent-Drop Grinding Method. Tropical Journal of Pharmaceutical Research, 17 (6), 997-1002.

[30] Smith, A. J., Kavuru, P., Wojtas, L., Zaworotko, M. J, Shytle, R. D. (2011). Cocrystals of Quercetin with Improved Solubility and Oral Bioavailability. American Chemical Society.

[31] Sowa, M., Slepokura, K., Jon, E, M. (2014). Solid-State Characterization and Solubility of a Genistein-Caffeine Cocrystal. Journal of Molecular Structure, 1076, 80-88.

[32] Sowa, M., Ślepokura, K., Jon, E. M. (2013). Cocrystals of Fisetin, Luteolin and Genistein with Pyridinecarboxamide Coformers: Crystal Structures, Analysis of Intermolecular Interactions, Spectral and Thermal Characterization. Royal Society of Chemistry, 15 (38), 7696-7708.

[33] Sari, Y. N., Zaini, E., Ismed, F. (2019). Peningkatan Laju Disolusi Piperin dengan Pembentukan Multikomponen Kristal Menggunakan Asam Nikotinat. Jurnal Sains Farmasi \& Klinis, 6 (2), 180-185.

[34] Zaini, E., Afriyani, A., Fitriani, L., Ismed, F., Horikawa, A., Uekusa, H. (2020). Improved Solubility and Dissolution Rates in Novel Multicomponent Crystals of Piperine with Succinic Acid. Scientia Pharmaceutica, 88 (21), 1-13.

[35] Pantwalawalkar, J., More, H., Bhange, D., Patil, U. (2020). Novel Curcumin Ascorbic Acid Cocrystal for Improved Solubility. Journal of Drug Delivery Science and Technology, 1-11.

[36] Sanphui, P., Goud, N. R., Khandavili, U. B. R., Nangia, A. (2011). Fast Dissolving Curcumin Cocrystals. American Chemical Society, 11, 4135-4145. 